\title{
The real exchange rate and the renminbi
}

\section{Rod Tyers and Ying Zhang}

\section{Introduction}

China's renminbi (RMB) has been at the centre of political debates over current account imbalances for more than a decade. In scholarly circles, while a few, including McKinnon (2006), argue that a renminbi appreciation would not address the imbalances of concern to the United States, numerous studies have supported the view that the currency is undervalued-by margins ranging from 'small' to as high as 50 per cent ${ }^{1}$ - and some conclude that a unilateral appreciation of the renminbi is essential (for example, Cline 2005). Expectations that China's exchange rate should be appreciating are based commonly on the Balassa (1964) - Samuelson (1964) hypothesis (BSH). This implies a positive relationship between economic growth and the underlying real exchange rate, driven by productivity catch-up in developing countries' tradable sectors and, in association, rising wages and prices in their non-tradable sectors.

Empirical evidence from studies by Lu (2006), Fogel (2006) and Tyers et al. (2008) suggests that China's tradable productivity growth has been double that of the United States since the early 1990s (Gordon 2003, 2006). The productivity pattern therefore appears to support a real appreciation relative to the United States consistent with the BSH. More controversial, however, is the expectation that the productivity gains force relative growth in real wages. That this is true to some degree is clear from the official statistics (Garnaut and Huang 2006). The real wages of non-hukou workers were, however, less formally recorded and Meng and Bai (2007), among others, suggested that these grew more slowly, if at all, at least until the mid 2000s. The BSH then posits that faster Chinese growth in both tradable productivity and real wages should cause a rise in relative nontradable (mainly service) prices, which is also observed through the mid 2000s ( $\mathrm{Lu}$ 2006; Tyers et al. 2008). In spite of all this evidence supporting the BSH, there was no significant real appreciation between the mid 1990s and 2004.

1 See, for example, Frankel (2004); Wang (2004); Goldstein (2004); Coudert and Couharde (2005); Tyers et al. (2008); and Cheung et al. (2007a, 2007b). 
The resolution of this puzzle requires a number of generalisations of the BSH, most significant among which is the relaxation of the assumption that the law of one price applies for all traded goods. This greatly broadens the set of determinants of the real exchange rate. The net effect of China's rapid economic growth on its real exchange rate is, then, seen to depend on the sources of that growth and the consequent pattern of endowment changes and sectoral distributions of productivity growth and tradability. Of considerable importance in the decade to the mid 2000s is the short-run impact of China's widening current account surplus, which stemmed from its extraordinarily high total saving rate and the World Trade Organisation (WTO) accession trade reforms.

We show that a strong reversal of the earlier tendency for the real exchange rate to depreciate occurred after 2004, raising China's production costs by onethird, relative to the United States, by 2008. We explore this change and discuss its determinants, noting mounting evidence not for a return to the dominance of the BSH but instead for a tightening labour market associated, at least in part, with improved rural terms of trade. Turning to macroeconomic policy, we then examine the controversy over China's extensive holdings of official foreign reserves, finding these to be a consequence of its capital controls and its high saving rate. We show, however, that, by international standards, they do not appear to represent extraordinary holdings of generic foreign assets. We then examine the exchange rate target as monetary policy, concluding that, should the Chinese government respond to international pressure with a premature nominal revaluation or some form of constraint on its exports, the consequences would be harmful to both Chinese and global interests.

The next section offers a brief summary of an analysis of China's real exchange rate path to the mid 2000s, showing the importance of the saving rate and trade reforms in this period. This is followed by a review of evidence of the reasons for the more recent appreciating trend and then a discussion of the role of China's macroeconomic policy. A summary of policy implications concludes the chapter.

\section{The 1994-2004 puzzle}

If the average product of labour in the non-tradable (largely services) industries is the same across countries while the corresponding average product in tradable industries, $A T$, is lower in poor countries, the BSH yields the following elegant relationships between the underlying real exchange rate, $e R$, and the ratios of home and foreign values of $A T$, non-traded prices, $p N$, and wage rates, $W$ (Equation 9.1). ${ }^{2}$

2 For the derivation of this relationship, see Golley and Tyers (2007). 


\section{Equation 9.1}

$e_{i}^{R}=\left(\frac{p^{N}}{p_{i}^{N}}\right)^{\theta}=\left(\frac{A^{T}}{A_{i}^{T}}\right)^{\theta}=\left(\frac{W}{W_{i}}\right)^{\theta}$

Here, the real exchange rate is defined as the value of the home product bundle relative to a corresponding bundle in foreign region $i$. It is the number of foreignsourced product bundles that can be obtained if one home product bundle is traded away. According to the $\mathrm{BSH}$, an economy that is growing faster than its trading partners also has:

1. faster tradable productivity growth, $\hat{A}^{T}>\hat{A}_{i}^{T}$

2. faster wage growth $\hat{W}>\hat{W}_{i}$

3. relative service price inflation $\hat{p}^{N}>\hat{p}_{i}^{N}$

4. an appreciating real exchange rate $\left(\hat{e}_{R}>0\right)$.

The hypothesis then implies that, if developing countries are poorer because their tradable labour productivity is lower, their comparatively rapid growth should be associated with real appreciations against their richer trading partners. Given that this is a widely discussed theory of the real exchange rate, it is not surprising that China's growth surge since the early 1990s has been accompanied by the widespread anticipation of a real appreciation.

While wider empirical evidence in support of the BSH is mixed, when price levels are compared through time and across large numbers of countries, the pattern of real appreciation among the more rapidly growing countries is observed (Cheung et al. 2007b; Bergin et al. 2006). For the case of China, we observe convincing evidence of faster tradable productivity growth (Table 9.1) and higher price inflation in the service sector ('tertiary' industry and construction) through the mid 2000s (Figure 9.1). Yet, as Figure 9.2 shows, no real appreciation was observed until after 2003. For a reflection of this, we use monthly data for Chinese and US producer price indices in Figure 9.3, which shows the same real depreciating trend through the mid 2000s with a subsequent sharp real appreciation in the lead-up to the global financial crisis. Clearly, to understand the path of China's real exchange rate, we require a generalisation of the BSH, and this means relaxing its key assumptions. 
China; The Next Twenty Years of Reform and Development

Table 9.1 Contributions to China's real exchange rate change, 1997-2006 (per cent)

\begin{tabular}{l|l}
\hline Faster tradable productivity growth-Balassa Samuelson & +1.6 \\
\hline Faster skill growth & -0.6 \\
\hline WTO accession trade reforms & -4.2 \\
\hline Influx on the financial/capital account of North America & -0.4 \\
\hline Efflux on the financial/capital account (high saving rate) & -4.8 \\
\hline Net effect over 1997-2006 & -8.1 \\
\hline
\end{tabular}

Source: Tyers, R. and Golley, J. 2008, 'China's real exchange rate puzzle', Journal of Economic Integration, vol. 23, no. 3, pp. 547-74.

Figure 9.1 Chinese sectoral price indices, 1990-2009
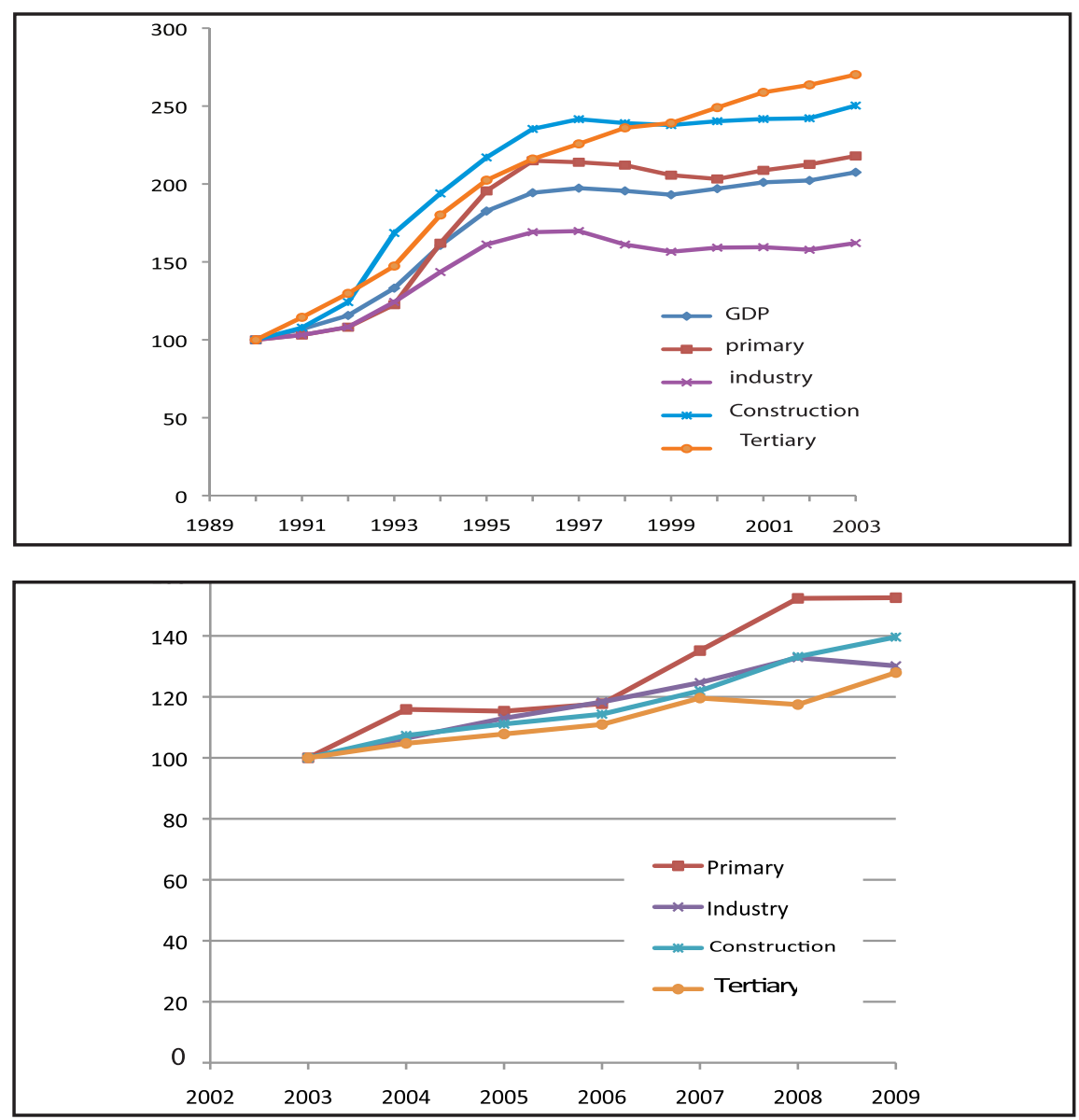

Note: These are sectoral price indices for 'primary industry', which is agriculture and rural services, 'industry', which is primarily manufacturing and 'construction' (the latter two making up the 'secondary' sector); and 'tertiary industry', which is other services.

Source: The price indices are implied by volume and value data from National Bureau of Statistics (NBS) 2009, China Statistical Yearbook 2009, China Statistics Press, Beijing. 
Figure 9.2 The Mainland China-US real exchange rate on GDP prices

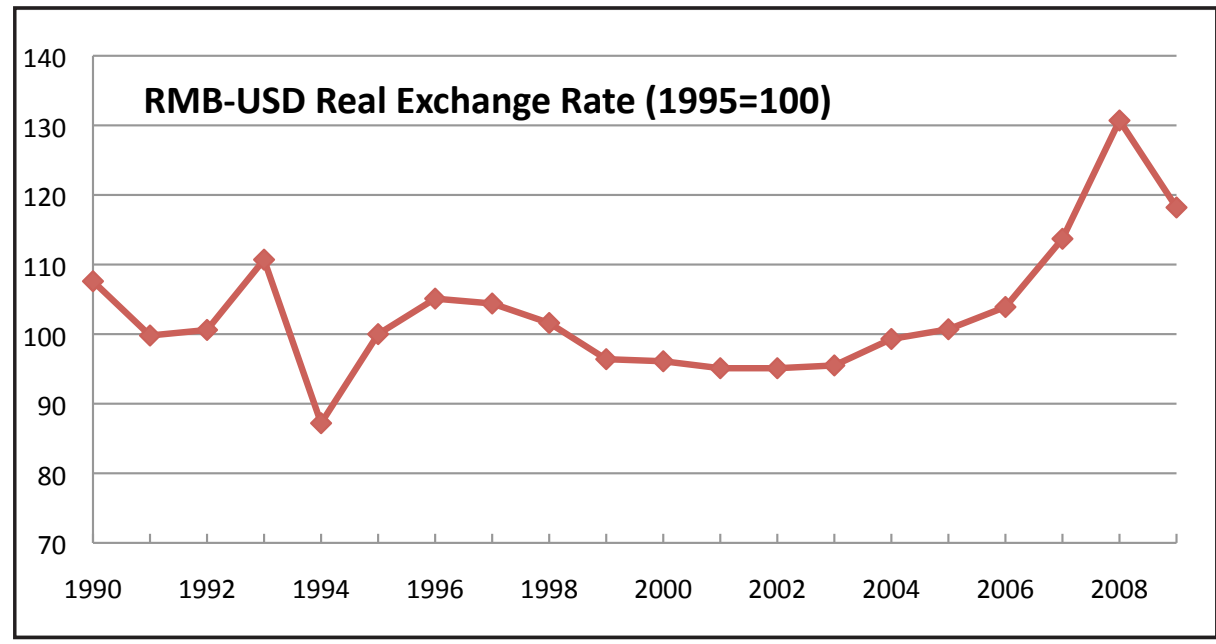

Note: These are indices of nominal bilateral rates between Mainland China and the United States, deflated according to $e_{R}=E \times P_{Y} / P_{Y}^{U S}$, where $E$ is the nominal exchange rate in US dollars per unit of local currency, $P_{Y}$ is the local GDP price and $P_{Y}$ is the corresponding US GDP price.

Source: International Monetary Fund (IMF) 2009a, International Financial Statistics, International Monetary Fund, Washington, DC.

Figure 9.3 The Mainland China-US real exchange rate on producer prices

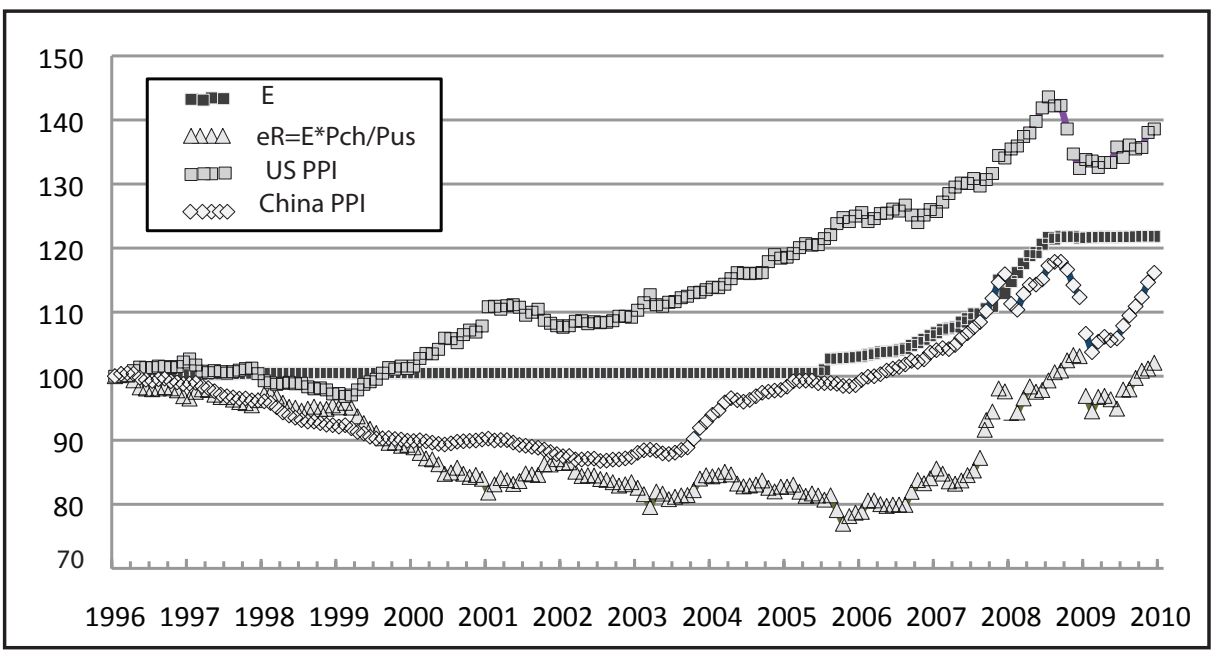

Notes: Here the home prices are, for the United States, the producer price index and, for China, the corporate goods price index. The Chinese index has more coverage of commodities and services, so this is a less than perfect comparison. The implied real exchange rate is in black.

Sources: International Monetary Fund (IMF) 2009a, International Financial Statistics, International Monetary Fund, Washington, DC; National Bureau of Statistics (NBS) 2009, China Statistical Yearbook 2009, China Statistics Press, Beijing; the Bureau of Labor Statistics, USA. 


\section{The law of one price for tradable goods}

Failures of the law of one price have been observed for tradable goods in specific instances (for example, Bergin et al. 2006; Crucini et al. 2005; Drine and Rault 2005). Goods and services are not homogeneous across countries but are differentiated at minimum by country of origin. ${ }^{3}$ Supply and/or demand-side shocks that raise the volume of tradable production move the home country down the global demand curves for its product varieties, reducing its supply prices and resulting in deterioration in its terms of trade and a depreciation of its real exchange rate. Home factor endowment growth and changes in policy that lead to substitution in demand away from home products therefore also depreciate real exchange rates.

\section{Labour arbitrage}

In most developing economies, there is a Harris-Todaro gulf between wages in the modern and rural sectors. If labour mobility between the rural and industrial sectors is inferior to that between the rural and service sectors (particularly the construction sector), industrial productivity growth does not necessarily drive up service wages or service costs — at least not to the same extent on average. ${ }^{4}$

\section{Closed capital account ${ }^{5}$}

The assumption that the real exchange rate depends only on interactions among countries associated with trade in merchandise is clearly violated in many of today's developing countries - and particularly in China. Its violation, in concert with failures of the law of one price for tradable goods, means that any influx of payments (in the form of a foreign direct investment, portfolio capital flow or a repatriation of official foreign reserves) raises home aggregate demand. Since tradable goods are supplied more elastically via imports than are non-tradable goods - which depend on home resources - such an influx must raise relative non-tradable prices and therefore appreciate the real exchange rate. Conversely, effluxes such as China's extraordinary foreign reserve accumulations cause real depreciations.

Using a multi-region, multi-product dynamic simulation model of the world economy, Tyers and Golley (2008) evaluate the implications of a variety of shocks for China's real exchange rate. They find that, in the short run, the real

3 This is a standard assumption in the most widely used numerical models of open economies and global trade. See, for example, Dixon et al. (1982); McKibbin and Sachs (1991); Hertel (1997); and Dixon and Rimmer (2002).

4 Chang and Tyers (2008) offer evidence for this.

5 Here we adopt a working definition of the capital account as broadly including all flows on the balance of payments associated with asset acquisition. As such, it encompasses the more narrowly defined capital account, the financial account and official reserve transactions. 
exchange rate is most responsive to financial capital flows, so that China's excess saving tends to depreciate the real exchange rate. In the medium run, the BSH force (relative productivity growth in tradable industries) is strong, as is the effect of trade reforms that divert domestic demand away from home products and therefore depreciate the real exchange rate. In the long run, the real exchange rate depends sensitively on factors affecting the cost of non-traded services. They then employ their model to decompose the real depreciating trend between the mid 1990s and the mid 2000s. The particular real exchange rate chosen for this analysis is that between China (including Hong Kong and Taiwan) and North America. This rate depreciated by 8 per cent in the period of interest. Its decomposition is summarised in Table 9.1.

Higher Chinese productivity growth is seen to have offered the expected BSH appreciating force. Net financial outflows on China's balance of payments and inflows on the North American balance of payments both tend to depreciate the Chinese real exchange rate. Similarly, skill acquisition (which reduces the cost of supplying mainly skill-intensive services) and trade reform offer the expected depreciating forces. In combination, the current account imbalances in China and North America contribute a real depreciation of more than 5 per cent. Surprisingly significant, however, is the depreciating effect of WTO accession trade reforms, which contribute more than 4 per cent to the overall real depreciation. In the end, these current account imbalances prove to be, in combination, the most important depreciating forces to the mid 2000s.

The significance of this for China is clear from Figure 9.4, which shows that the saving-investment gap (the current account surplus) expanded substantially after the East Asian financial crisis. This expansion in net outflows diverted domestic demand abroad and placed downward pressure on China's real exchange rate. To see this, note that the equality of net inflows of payments on the capital account (net outflows on the current account) ${ }^{6}$ to the investment-saving gap follows from the standard aggregate expenditure and disposal identities. ${ }^{7}$ Defining net inflows as positive, the capital account surplus can be written as: $K A=S_{N F}-\Delta R=I-S_{D}$, in which $I$ is investment, $S D$ is total domestic saving, $S N F$ (net foreign saving) is net private inflow on the financial account and $\Delta R$ is the annual addition to official foreign reserves. In the presence of capital controls, $S_{N F}$ was roughly equal to officially approved inward foreign direct investment (FDI). Both sides of the equation are negative in the case of China, indicating net outflows. Extraordinarily, even though investment accounts for

6 For our working definition of the 'capital account', KA, see the next note.

7 The right-hand side of this identity stems from the combination of aggregate expenditure on GDP, $Y=C+$ $I+G+X+\mathrm{M}$; the fact that GNP is $Y N=Y+\mathrm{N}$, where $\mathrm{N}$ is net factor income from abroad; the GNP disposal identity, $Y N=C+T+\mathrm{S}$, and the balance of payments, $B o P=O=K A+C \mathrm{~A}$, where the current account is $C A=X-M+\mathrm{N}$. 
45 per cent of China's GDP, more than half of its GDP is saved. In explaining the real depreciating trend, however, the key observation is that the savinginvestment gap was increasing through the mid 2000s.

Figure 9.4 China's investment-saving and external balances (percentage of GDP)

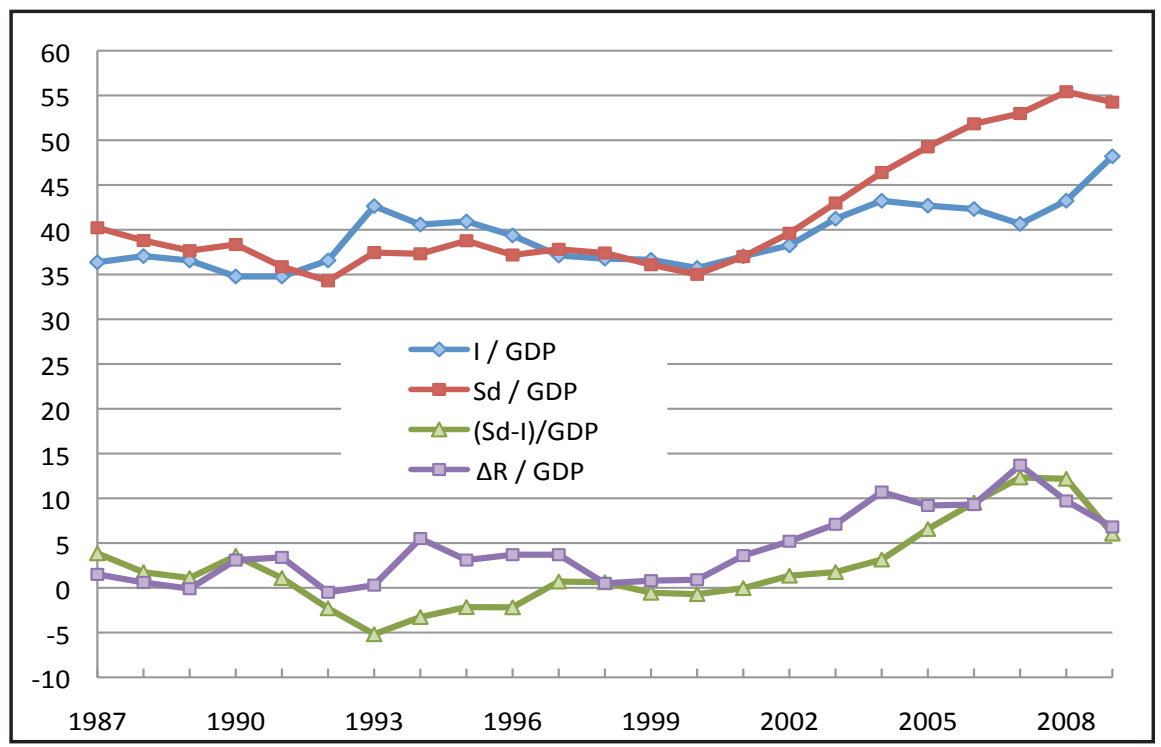

Note: Since errors and omissions are large, we have adjusted the least accurately measured items in each sub-account (usually net factor income and net private flows on the financial account) to ensure balance.

Sources: International Monetary Fund (IMF), 2009a, International Financial Statistics, International Monetary Fund, Washington, DC; International Monetary Fund (IMF), 2009b, World Economic Outlook Database, April, International Monetary Fund, Washington, DC; National Bureau of Statistics (NBS) 2009, China Statistical Yearbook 2009, China Statistics Press, Beijing.

\section{The real appreciation after 2004}

The exchange rate reforms launched by the Chinese authorities in July 2005 were intended to at least demonstrate a departure from the de facto fixed US dollar peg, nominally allowing the currency to fluctuate by up to 0.3 per cent each day. The appreciation accelerated in 2007 amounting to an accumulated 20 per cent by July 2008, after which the global financial crisis induced the Chinese government to return to the de facto US dollar peg. The 2004-2008 round of revaluation was accompanied by significant domestic inflation, implying a substantially larger appreciation of the underlying real exchange rate (Figure 9.2)-amounting to at least 30 per cent. As is evident from Figure 9.3, the difference between the bilateral nominal and real appreciations was associated with faster growth of China's producer prices than those of the United States. 
More recently, as Figure 9.3 shows, the underlying real appreciating trend has resumed. Accordingly, to control domestic inflation, official "flexibility" was restored as of June 2010.

Changes in the path of the real exchange rate since 2004 are too recent for a detailed decomposition. The GFC aside, a clear tendency toward real appreciation is evident, however. In what follows, we discuss a number of alternative explanations for this appreciating trend.

\section{Decreasing current account surplus}

After a rapid increase in the early 1990s, household saving rates fluctuated between 20 and 25 per cent during 1997-2006 (Tyers and Lu 2009). The initial surge in household saving was associated with the 1990s round of privatisation and restructuring, which increased household funding responsibilities for health, education and retirement expenses. In more recent years, the government has embarked on national schemes for health and retirement insurance, including the extension of medical pension insurance to cover rural areas and the establishment of urban subsistence security systems (Chamon and Prasad 2008; Wen 2008). These have lessened this concern, leading to at least the stabilisation of household saving rates. At the same time, a surge in government spending began with the onset of the global financial crisis in 2007. This reduced the government's contribution to national saving. As shown in Figure 9.5, the Chinese current account surplus has stabilised since 2005 and recently contracted. The previous period of real depreciation was associated with the expansion of this surplus and hence the diversion of increasing shares of Chinese income into expenditures abroad. The cessation of this trend would at least stem further real depreciation.

\section{Increasing oligopoly rents}

$\mathrm{Lu}$ et al. (2008) point out that Chinese state-owned enterprises (SOEs) still dominate industries such as metals, motor vehicles, aircraft, transport, telecommunication, finance and insurance and that they became extremely profitable during the 2000s. Tyers and $\mathrm{Lu}$ (2009) attribute these profits to oligopolistic behaviour and see the associated rents as having expanded with the post-WTO accession growth surge, financing the huge corporate savings of the period. The effect of these rents on China's real exchange rate has two channels. First, higher mark-ups in largely non-traded industries raise prices and hence cause appreciation. Second, the rents gained by SOEs make up a primary part of corporate saving, which has tended to divert Chinese expenditure abroad and thus to depreciate the real exchange rate. As Tyers and Lu showed, the latter effect was dominant to 2005. The more recent decline in the corporate saving rate (Bayoumi et al. 2009) could have shifted this balance towards the appreciating effect of mark-ups. 
Figure 9.5 Real wage growth in agriculture

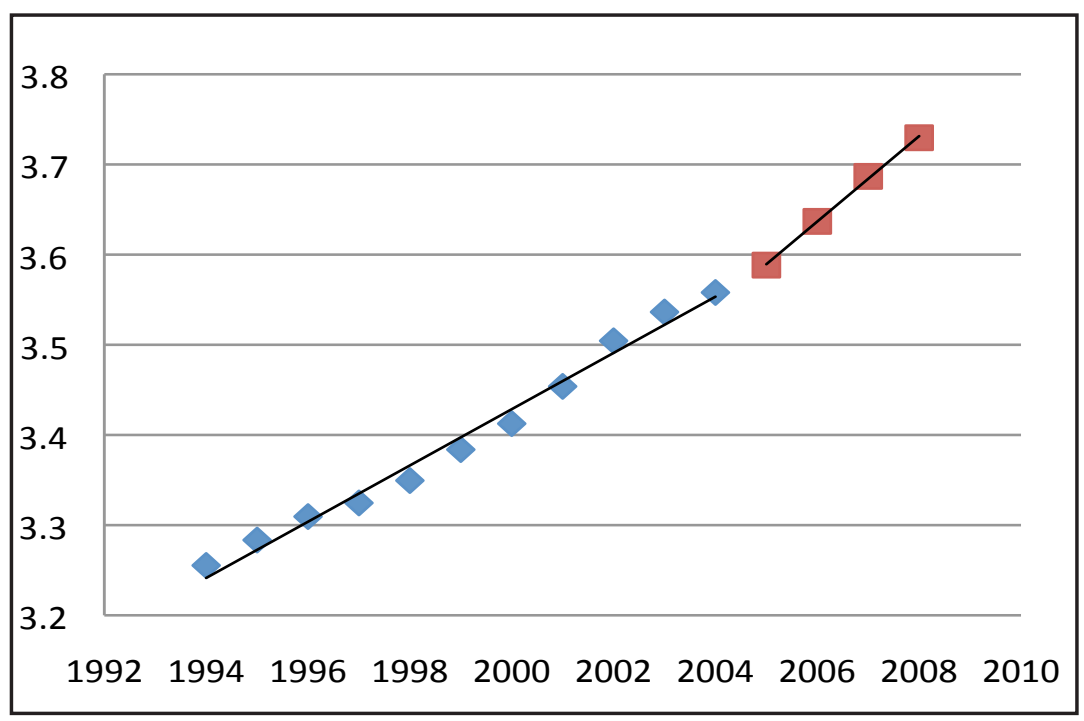

Note: The vertical axis is the log of the real wage index where the agricultural nominal wage is deflated by the consumer price index (CPI).

Source: The nominal wage by sector and the CPI are from National Bureau of Statistics (NBS) 2009, China Statistical Yearbook 2009, China Statistics Press, Beijing.

\section{Slowdown of trade reform}

China's 2001 WTO accession saw a wide range of tariff cuts and market-opening policy changes. Since then trade reform has slowed. ${ }^{8}$ As discussed previously, trade liberalisation depreciates the real exchange rate so this slowdown might be seen as at least relaxing pressure for depreciation. Yet trade reforms are never Pareto improving without compensation. The sector bearing the most negative effects from WTO accession has been agriculture, the stagnation of which in the early years after accession probably contributed to the substantial rural-urban migration of the period (Chang and Tyers 2008; Rees and Tyers 2008). Since then a major concern of the central government has been the welfare of farmers and other rural dwellers. Unlike the corresponding experiences of Japan, Korea and Taiwan during their growth surges, in China, because of its WTO commitment, it has not been able to address the rural-urban divide using trade protection (Anderson and Hayami 1986; Anderson 2009; Duncan et al. 2008). A consequence has been a trend from negative assistance to agriculture in the early reform period to positive and significant protection today, channelled via

8 According to the World Trade Organisation's Trade Policy Review (WTO 2008), the tariff is still one of China's main trade policy instruments. The overall average applied MFN tariff was 9.7 per cent in 2007- the same as in 2005. The average applied MFN tariff rates for agricultural and non-agricultural products were 15.3 per cent and 8.8 per cent, respectively — also the same as in 2005. 
domestic marketing, transport, storage and other budgetary measures - allowed under WTO rules for developing countries. ${ }^{9}$ Beyond agriculture, a number of trade-biased policies have emerged that cut against the spirit of the preaccession reforms. Since 2005, the value-added tax (VAT) rebate for exporting firms has been raised nine times - up to 17 per cent - covering approximately 3800 export products, including textiles, clothing, toys, machinery, electric appliances, medicines, communication devices and steel (Ministry of Commerce of the People's Republic of China 2009). Such export-encouraging policies divert home supplies abroad, raising the relative prices of domestic goods and hence appreciating the real exchange rate.

\section{Rising relative wage costs}

The sectoral price indices in Figure 9.1 are revealing in that, since the mid 2000s they do not show any rise in the price of services (the 'tertiary' and construction sectors) relative to the tradable-goods sectors. This suggests that the appreciation since 2004 is not due to the BSH force (relatively high productivity growth in China's tradable sectors). Indeed, the striking change is in the price index for primary products, indicating a substantial improvement in the agricultural terms of trade. While this is due in part to higher prices of import-competing commodities, we have already seen that there have been a number of favourable changes to policies affecting agriculture and the rural sector generally. These changes would have raised the marginal product of rural labour and therefore the incentive required for rural workers to migrate to eastern cities.

Regression results suggest a structural change in real wage growth for the agricultural and construction sectors about 2004, as indicated in Figure 9.5. The labour forces in these sectors are mainly unskilled and the rural labour market is the source of most non-hukou workers in construction, other services and manufacturing. The official agricultural real wage grew at 3.1 per cent per annum (with a standard error of 0.0012) in the period 1994-2004 and at 4.7 per cent per annum (with a standard error of 0.002) in the period 2005-08. ${ }^{10}$

In their study of the real wages of unskilled factory workers in Guangdong, Meng and Bai (2007) used payroll data to ensure the inclusion of non-hukou workers. They show a much smaller annual growth rate of between 0.5 and 1.5

9 Huang et al. (2009) show the trend in assistance to agriculture clearly in their Table 3.5. More recently, the speech by Wen (2010) indicates the central government's plans to raise the agricultural subsidy to RMB133 billion in 2010. The same speech indicates that agricultural tax reductions were carried out in Anhui Province in 2000 and were then extended to 30 provinces in 2003. By 2005, agricultural production taxes were completely cancelled in 28 provinces. Farmers' benefits were estimated at RMB133.5 billion per annum. 10 The growth rates were obtained from a simple ordinary least squares (OLS) regression of the log of the nominal agricultural wage deflated by the consumer price index (CPI) against time. The standard errors on the growth rate coefficients in both regressions are very small, suggesting that the growth rates are significantly different. 
per cent per annum up to 2004, controlling for education and firm tenure. The take-off in rural wages after that time suggests, however, that real non-hukou rates have increased since and this is to be expected from the improvements in net returns from agricultural activity. Increasingly, it is likely that potential 'floating workers' are choosing to continue their rural employment. Anecdotal indications of tightening labour markets have been abundant, including of increased labour unrest suggesting improved labour-market power in manufacturing provinces. ${ }^{11}$ What is evident is a slowing of urban labour supply growth, which drives up the cost of tradable and non-tradable goods relative to China's trading partners and hence causes the real exchange rate to appreciate. While this seems to be associated with agricultural incentives in the short termalong with improvements in infrastructure that have boosted local services sectors - in the long term, the prospect can only be for a continuation. This is because demographic change already long in train will see China's total labour force begin to decline during the next decade (Cai and Wang 2006; Golley and Tyers 2006). In short, this change could be heralding the end of the era of the Dooley et al. (2003) 'revived Bretton Woods trade account' regions generating export growth on the back of surplus rural labour - at least as far as China is concerned (Feenstra and Hong 2007).

\section{Macroeconomic policy and the renminbi}

The real and nominal exchange rates are linked by definition as $e_{R}=P_{Y} /\left(E P_{Y}^{*}\right)=E \cdot P_{Y} / P_{Y}^{*}$, where $E$ is the nominal exchange rate (in foreign currency per unit of home currency), $P_{Y}$ is the price of the home product bundle (the GDP price) and $P^{*}{ }_{Y}$ is the corresponding foreign gross domestic product (GDP) price. Since the foreign price level is outside the realm of home monetary policy, changes in the real exchange rate (determined as discussed in the previous sections) are transmitted domestically through changes in either the nominal exchange rate or the home price level. The choice as to how these are combined is a matter for home monetary authorities. At one extreme, a real appreciation can be transmitted as a nominal appreciation (inflation targeting) or, at another, as inflation (exchange rate targeting). This is complicated, particularly in China's case, by the dependence of the real exchange rate on capital account flows, which are dominated by reserve accumulation, where the choice of reserves is also an instrument of monetary policy.

11 Strikes at key joint-venture plants and other activism led to substantial increases in manufacturing wages in 2009 in the engine-room provinces of Guangdong and Zhejiang (Gardner 2010). 


\section{Reserve accumulation and monetary mercantilism}

China's reserve accumulation has led to allegations of 'monetary mercantilism' (Aizenman and Lee 2006). It is implied that reserve accumulation is chosen freely in order to keep the real exchange rate low. In our view, the monetary mercantilist critique is misplaced. The root of its unfairness is evident from the identity derived previously, $K A=S_{N F}-\Delta R=I-S_{D}$, and therefore, $\Delta R=S_{D}-I+S_{N F}$, in which $S_{N F}$ includes approved FDI and illegal private inflows. As long as total domestic savings exceed investment and capital controls prevent the matching of inward FDI by private outflows, $\Delta R$ must be positive. Indeed, we can state that China's current account surplus must be matched by reserve accumulation and the imbalance is not amenable to feasible changes in macroeconomic policy, narrowly defined, ${ }^{12}$ if:

- the capital controls are justified on stability grounds

- the high private saving rate is impervious to macroeconomic policy in the short run

- as it approaches 50 per cent of GDP (Figure 9.4), investment must be near absorptive capacity.

- government revenue is increasing so quickly that the government cannot easily offset private saving with public 'dis-saving'.

Consider each of these four conditions in turn. The capital controls are conceptually simplest. They stem from 'fear of floating' and short memories of the currency run with which China was threatened in the late 1990s during the East Asian financial crisis. Moreover, some suspicions remain in the People's Bank of China (PBOC) as to the prudential reliability of China's commercial banks in exchanging large volumes of foreign currency. Financial institutions are perceived variously as not sufficiently distant from decades of soft budget constraints associated with the channelling of government subsidies to stateowned enterprises (SOEs) through accumulated debt. And there are concerns that the commercial banks lack access to or sufficient experience with derivative markets for currency and debt instruments to do the necessary hedging. Though Ma and McCauley (2007) vouch for their continued effectiveness, the controls are slowly being relaxed.

As indicated earlier, China's high private saving rate is due to comparatively high household saving and extraordinarily high corporate saving. While the former has ceased to rise and is expected to decline slowly with time as health and retirement insurance systems develop (Chamon and Prasad 2008), the latter,

12 This is a general view also taken by Xiao (2006), who posits that 'structural factors' and transaction costs cause China's economy to adjust with a lag, implying that the current account surplus is not amenable to macroeconomic policy in the short run. 
as argued by Tyers and Lu (2009), is due to the profitability of key SOEs and is therefore an issue for industrial policy, which will take time to resolve. The causes of high saving are therefore deeply structural and the subject of longterm programs of microeconomic policy reform. None is amenable to action by the central bank alone.

As noted by Xiao (2006), it has been suggested that the surplus of saving over investment implies that the rate of investment is too low. At more than 45 per cent of its GDP, however, China's investment is extraordinarily high. It is difficult to imagine how additional projects might be conceived and implemented given service sector planning and facilitation constraints. ${ }^{13}$ Moreover, China's low official domestic financing rates notwithstanding, recent surveys by the PBOC show that a very substantial proportion of investment still takes place through the informal sector at rates that remain high by international standards. It will take some time yet for financial intermediation costs in China to fall to industrialised-country levels, so financing costs must continue to be a brake on investment. ${ }^{14}$

Finally, before the global financial crisis, China's fiscal policy maintained a tight balance between revenue and expenditure. During the crisis, the government committed to a substantial fiscal expansion, including an ambitious program of infrastructural investments, with a view to reducing the national saving rate and raising private consumption expenditure. This prospect faces two difficulties. First, public infrastructure investment to that point already absorbed a larger share of GDP in China than in any other developing country of comparable income per capita (Roland-Holst et al. 2005). Second, revenue collections have grown faster than China's GDP as its tax system has improved in effectiveness and as more of China's economic activity has occurred in the relatively taxable 'modern' sectors. It is yet unclear whether the accelerated spending has outpaced revenue collection. Certainly, there has yet been no dramatic rise in government bond issues. ${ }^{15}$

This support of the 'four ifs' suggests that the Chinese government has little true discretion over its rate of reserve accumulation and therefore over the rate at which domestic income is diverted into expenditure abroad, weighing on its

13 Evidence of "white elephant" projects notwithstanding, this is a point over which there is much disagreement.

14 Tyers and Golley (forthcoming) model the effect of high financial intermediation costs on China's growth rate.

15 According to the Ministry of Finance, during 2006-09, the Chinese government issued bonds worth RMB888 billion (2006), RMB798 billion (2007), RMB862 billion (2008) and RMB778 billion (2009) — showing no increasing trend. Besides this, RMB1550 billion in special bonds were issued in 2007 and exchanged with the PBOC for the equivalent from its stock of reserves. The result was a substitution on the asset side of about 8 per cent of GDP from reserves to domestic credit. 
underlying real exchange rate. The extent to which the national saving rate has stabilised very recently suggests, however, that reserve accumulation could be a more neutral force in future.

\section{Liquidity and sterilisation}

Through 2008 at least, the PBOC absorbed foreign currency inflows (export revenue) net of import costs because - short of long-term reforms affecting financial depth and while capital controls remained-the Chinese commercial banks could not move the required volume of foreign currency. This required acquisition of the foreign currency surplus with newly minted domestic currency. To avoid excess liquidity, annual reserve increments were sterilised. PBOC holdings of domestic credit were insufficient for this sterilisation, however, so 'sterilisation bonds' were issued on the debit side of the balance sheet shown in Table 9.2.

Table 9.2 The balance sheet of the People's Bank of China, ca. 2009

\begin{tabular}{l|l}
\hline Assets & Liabilities \\
\hline $\begin{array}{l}\text { Domestic credit, DC Central bank } \\
\text { claims on depository and other financial } \\
\text { corporations and on the central } \\
\text { government 13 per cent GDP }\end{array}$ & $\begin{array}{l}\text { The monetary base, MBCurrency and bank } \\
\text { reserves 43 per cent of GDP }\end{array}$ \\
\hline $\begin{array}{l}\text { Official foreign reserves, R55 per cent } \\
\text { of GDP }\end{array}$ & $\begin{array}{l}\text { Sterilisation bonds, SBDebt to the Chinese public } \\
13 \text { per cent of GDP } \\
\text { Other liabilities, OLIncludes government } \\
\text { ownership 12 per cent of GDP }\end{array}$ \\
\hline
\end{tabular}

Source: People's Bank of China (PBOC) 2009, Balance Sheet of Monetary Authority, People's Bank of China, Beijing.

Just as the reserves have come to dominate the asset side of the balance sheet, sterilisation bonds have assumed significance on the debit side. In effect, the PBOC has acted as a conduit for domestic savers who might otherwise acquire foreign assets but are restricted from doing so by capital controls. The pressure from abroad to revalue therefore creates two difficulties for the PBOC. First, since the assets of the PBOC are primarily in US dollars and its liabilities are in renminbi, too prompt an appreciation of the renminbi would result in substantial losses that would need to be covered in renminbi from the government budget. This concern was addressed in 2007 with the issue of US\$200 billion 
in government debt to be exchanged with the PBOC for reserve assets - the latter to be maintained by China's 'sovereign wealth fund': the state-run China Investment Company (CIC). ${ }^{16}$

As shown in Figure 9.6, this sterilisation process kept a lid on the monetary base as a proportion of GDP until the mid 2000s. Liquidity growth was substantial thereafter. It is our view that this has stemmed from continuing financial reforms, which have greatly expanded commercial bank intermediation (in place of preexisting and relatively costly informal credit structures and credit cooperatives). This has been valuable but the associated expansion in deposits has also boosted overall money supply growth, contributing since 2006 to inflationary pressure. The $\mathrm{PBOC}$ responded with higher bank reserve requirements and higher short interest rates. The latter added to speculative (illegal) private inflows driven by the expectation that the renminbi would be allowed to appreciate further, bringing upward pressure on the real exchange rate in the lead-up to the global financial crisis and since. As Figures 9.2 and 9.3 show, however, during the crisis the drop in export demand caused a temporary real depreciation. The return to the de facto peg then necessitated contractionary monetary policy and temporary deflation.

Figure 9.6 Dynamics of the PBOC's balance sheet: assets and liabilities as a percentage of GDP

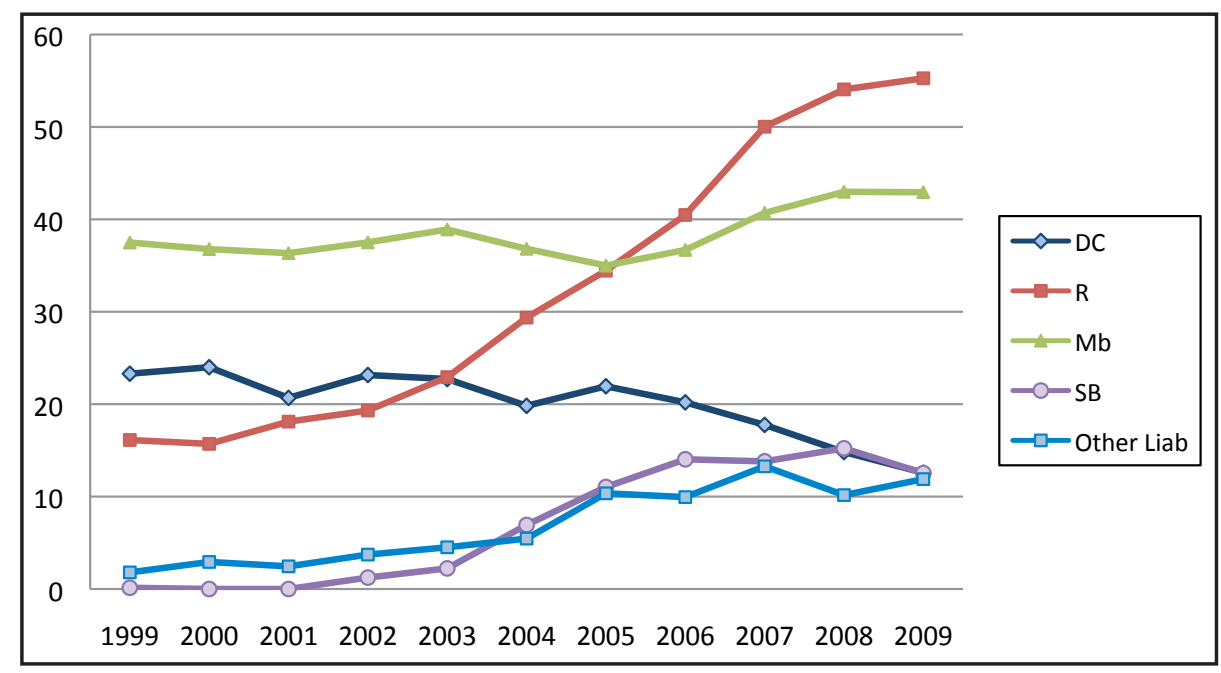

Source: The People's Bank of China.

16 The CIC takes the formerly established 'foreign exchange financial investment company' (the Hui Jin Co: literally translated as foreign exchange and gold) as its subsidiary. Hui Jin does mainly equity investment in domestic financial industries while its parent company, CIC, focuses on overseas investment. Thanks are due to the PBOC for this detail. 


\section{The effect of relaxing capital controls}

As capital controls are relaxed, a key issue will be the extent of private outflows on the financial account. Prasad et al. (2005) point to the potential for this to create a depreciating force as Chinese private investors seek to diversify their portfolios. The scale of this force depends on whether the PBOC's existing foreign reserves are the equivalent of the private sector's desired foreign holdings. A crude assessment of this can be made by comparing the foreign shares of collective portfolios across industrialised and developing countries. Assets are, however, many and various and net positions are poorly documented. For a sample of countries, we have constructed a crude approximation of foreign shares in collective portfolios using estimates of capital stocks and recorded flows on balances of payments. The results require a sceptical eye since capital stocks are measured differently across countries and foreign shares can be expected to be higher in smaller and more open economies irrespective of their levels of development - as in the cases of Hong Kong, Singapore and the United Kingdom.

The resulting foreign asset shares are listed in Table 9.3. The countries are then ranked on their estimated foreign shares in Table 9.4. Most striking is that, large official foreign reserves notwithstanding, China ranks rather low on the list, even when compared with other Asian developing countries. Its foreign share appears to have doubled between 2000 and 2005 and its ranking rose. By 2005, it ranked above Japan, Korea, Thailand, India and Brazil but below the other industrialised countries and Malaysia, Taiwan and Chile. Its ranking above Japan and the other two of the world's very large developing countries, India and Brazil, suggests that its foreign share could be on the high side, though none of these economies is as open as China already is to foreign trade and ownership (Lardy 2006). On the other hand, its ranking below the industrialised countries suggests that continued growth, combined with comparative openness, will take its share higher. At the very least, these results do not lend clear weight to the thesis that financial liberalisation will automatically raise private inflows and appreciate the renminbi. Moreover, a surge in private rebalancing outflows could prove a healthy outcome since the PBOC could readily offset this by repatriating its reserves and sterilising the inflow by liquidating its 'sterilisation bonds'. This would take the pressure off the CIC by restoring the PBOC's balance sheet to something more conventional as well as stabilising the home financial capital market. 
China; The Next Twenty Years of Reform and Development

Table 9.3 Estimates of the foreign share of total assets, selected countries

\begin{tabular}{|c|c|c|c|c|c|c|}
\hline \multirow[t]{2}{*}{ Country } & \multicolumn{6}{|c|}{ Ratio of foreign to total assets (\%) } \\
\hline & 2000 & 2001 & 2002 & 2003 & 2004 & 2005 \\
\hline China & 10 & 9 & 9 & 12 & 14 & 18 \\
\hline Hong Kong & 55 & 56 & 55 & 59 & 60 & 64 \\
\hline Japan & 9 & 12 & 12 & 14 & 14 & 17 \\
\hline Taiwan & 11 & 14 & 17 & 21 & 22 & 24 \\
\hline Korea & 11 & 13 & 13 & 15 & 17 & 16 \\
\hline Malaysia & 22 & 27 & 28 & 38 & 36 & 41 \\
\hline Singapore & 48 & 50 & 51 & 57 & 57 & 58 \\
\hline Thailand & 18 & 20 & 19 & 19 & 17 & 17 \\
\hline India & 6 & 9 & 9 & 11 & 12 & 11 \\
\hline Brazil & 5 & 6 & 8 & 8 & 7 & 5 \\
\hline Mexico & 7 & 8 & 7 & 8 & 9 & 9 \\
\hline Chile & 21 & 23 & 22 & 26 & 25 & 25 \\
\hline Australia & 15 & 17 & 17 & 18 & 19 & 21 \\
\hline United States & 22 & 19 & 18 & 22 & 25 & 35 \\
\hline European Union 15 & 30 & 33 & 30 & 34 & 36 & 47 \\
\hline United Kingdom & 63 & 63 & 52 & 54 & 54 & 68 \\
\hline
\end{tabular}

Notes: Shares are approximated as the quotient of foreign financial and physical assets and total financial and physical assets. The numerator is the stock of capital owned abroad plus official foreign reserves. The denominator is official foreign reserves plus the home capital stock plus the stock of capital owned abroad less that part of the home capital stock that is foreign owned plus M2 plus gold stocks. International capital ownership is approximated, in turn, by dividing current account net factor income flows by long-term bond rates.

Sources: For most countries, foreign reserves, money supplies, gold stocks, net factor income flows on current account balances and long-term bond rates are from the International Monetary Fund (IMF) various issues, International Financial Statistics, International Monetary Fund, Washington, DC. For Taiwan, these are from the Taiwan Statistical Data Book, 2006. For Chile, the money supply is from the Central Bank of Chile; for Australia, it is from the Reserve Bank of Australia; and for Singapore, it is from the Monetary Authority of Singapore. For China and India, bond rates are from Datastream and, for the European Union 15, Malaysia and Chile, the bond rates are from the Economist Intelligence Unit. All capital stock estimates are from the GTAP global database.

Table 9.4 Country rankings on foreign shares of total assets

\begin{tabular}{|c|c|c|c|c|c|}
\hline 2000 & 2001 & 2002 & 2003 & 2004 & 2005 \\
\hline $\begin{array}{l}\text { United } \\
\text { Kingdom }\end{array}$ & $\begin{array}{l}\text { United } \\
\text { Kingdom }\end{array}$ & Hong Kong & Hong Kong & Hong Kong & $\begin{array}{l}\text { United } \\
\text { Kingdom }\end{array}$ \\
\hline Hong Kong & Hong Kong & $\begin{array}{l}\text { United } \\
\text { Kingdom }\end{array}$ & Singapore & Singapore & Hong Kong \\
\hline Singapore & Singapore & Singapore & $\begin{array}{l}\text { United } \\
\text { Kingdom }\end{array}$ & $\begin{array}{l}\text { United } \\
\text { Kingdom }\end{array}$ & Singapore \\
\hline $\begin{array}{l}\text { European } \\
\text { Union } 15\end{array}$ & $\begin{array}{l}\text { European } \\
\text { Union } 15\end{array}$ & $\begin{array}{l}\text { European } \\
\text { Union } 15\end{array}$ & Malaysia & Malaysia & $\begin{array}{l}\text { European } \\
\text { Union } 15\end{array}$ \\
\hline
\end{tabular}




\begin{tabular}{|c|c|c|c|c|c|}
\hline Malaysia & Malaysia & Malaysia & $\begin{array}{l}\text { European } \\
\text { Union } 15\end{array}$ & $\begin{array}{l}\text { European } \\
\text { Union } 15\end{array}$ & Malaysia \\
\hline $\begin{array}{l}\text { United } \\
\text { States }\end{array}$ & Chile & Chile & Chile & $\begin{array}{l}\text { United } \\
\text { States }\end{array}$ & United States \\
\hline Chile & Thailand & Thailand & $\begin{array}{l}\text { United } \\
\text { States }\end{array}$ & Chile & Chile \\
\hline Thailand & $\begin{array}{l}\text { United } \\
\text { States }\end{array}$ & $\begin{array}{l}\text { United } \\
\text { States }\end{array}$ & Taiwan & Taiwan & Taiwan \\
\hline Australia & Australia & Australia & Thailand & Australia & Australia \\
\hline Korea & Taiwan & Taiwan & Australia & Korea & China \\
\hline Taiwan & Korea & Korea & Korea & Thailand & Japan \\
\hline China & Japan & Japan & Japan & China & Thailand \\
\hline Japan & China & India & China & Japan & Korea \\
\hline Mexico & India & China & India & India & India \\
\hline India & Mexico & Brazil & Brazil & Mexico & Mexico \\
\hline Brazil & Brazil & Mexico & Mexico & Brazil & Brazil \\
\hline
\end{tabular}

Source: Rankings on the foreign asset shares in Table 9.3.

\section{Unilateral appreciation scenarios}

If the tendency towards real appreciation since 2004- as shown in Figure 9.2is indeed due to labour-market tightening, it heralds a long-term appreciating trend. This will make it easy for the PBOC to allow a corresponding appreciation in the renminbi. Any decision to revalue faster than the underlying rate of real appreciation would require further monetary tightening and possibly a return to the growth-sapping deflation of the late 1990s.

McKinnon's (2004) sage preference for an East Asian dollar standard notwithstanding, the bilateral pressure from the United States for a renminbi revaluation is understandable in one respect. Despite the benefits accruing to the US economy from Chinese investment, its government perceives a substantial current account imbalance, a proportion of which stems from its bilateral trade with China, and it expects that a US dollar depreciation will help to correct it (Woo 2006). Not only does the inflexibility of the renminbi rate frustrate the US government - inciting the critical rhetoric (Bernanke 2006) and the draft legislation to 'punish' China (Callan 2007) - it causes frustration in Europe, where the burden of appreciation against the US dollar is greatest. ${ }^{17}$

Ironically, while the refusal by some other Asian countries to appreciate their currencies significantly against the renminbi might well be motivated by 'monetary mercantilism', as argued previously, we believe that the sluggishness

17 See RGE Monitor (2007a). European rhetoric also represents this view, as in a speech by Pascal Lamy, then EU Trade Commissioner, on 23 December 2003. 
of China's appreciation against the US dollar is motivated internally. The sticking point is a fear of financial (including exchange rate) volatility, confirmed by adherence to the peg during the global financial crisis. Were the Chinese government nonetheless to agree to revalue faster than the underlying rate of real appreciation, it could either undertake a substantial monetary tightening, and hence further deflation, or accelerate the underlying real appreciation with a return to distorted trade.

\section{Appreciation by monetary contraction}

In the absence of any substantial upward movement in the underlying real exchange rate, the PBOC could simply declare a higher US dollar/renminbi rate. This is the option advocated by Tung and Baker (2004), who suggest a 15 per cent one-off revaluation and argue that the risk of consequent deflation is minimal, due to inflationary pressure from other sources. In the absence of an underlying appreciation of the real exchange rate, this argument lacks foundation.

The defence of the stronger renminbi would require a contraction of the domestic money supply (or a slowdown in its growth) and a boost to domestic short-term interest rates and other financing barriers. If the revaluation were large enough, the result would likely be a return to the deflation of the late 1990s and this would hurt employment in the tradable-goods sector. Income would decline (or grow more slowly), as would consumption and saving. Slower employment growth in the modern sector would reduce capital returns and, combined with higher financing costs, this would also contract investment (or reduce its growth), so the implications for China's external imbalance would then depend on the relative size of the saving contraction. For external balance there are, therefore, two cases to consider.

First, if Chinese households are optimistic, they expect that the contraction is temporary and unrestrained growth will be restored in the future. Faced with reduced current income, they would then smooth consumption by reducing current saving. Even with such a reduction in the saving rate, however, simulations presented by Tyers and Zhang (2010) show that the effect of lower employment growth on capital returns also causes a fall in investment. The value of the saving decline is larger in magnitude, however, and the net effect is to reduce China's current account surplus. There is therefore a real appreciation against North America and a slight reduction in the latter's current account deficit. In addition, there is a slight increase in North America's politically sensitive industrial employment, though this comes at the expense of a servicesector employment contraction due to North America's real depreciation against China. Both China and North America suffer losses in overall GDP and real income per capita. The loss in China is substantial, however, amounting to almost a year's growth. 
A second possibility is that Chinese households are pessimistic and believe that the contraction is permanent. In response to the monetary contraction and reduced income, they would then exhibit behaviour seen in Japan in the 1990s - smoothing their consumption forward and raising their saving rate. ${ }^{18}$ This exacerbates the contraction in Chinese economic activity and income. Moreover, because saving does not fall and investment does, China's current account surplus is raised. The additional financial outflow causes a real depreciation, suggesting that, to achieve a particular nominal appreciation target, the monetary contraction in this case would need to deliver a larger deflation than before. Internationally, this shock reduces global interest rates and raises North America's current account deficit. Even though there are small gains in North America's terms of trade and real income, the exacerbation of current account imbalances and the associated decline in industrial employment would further frustrate the United States politically. It is difficult to conclude other than that there is little to be gained from renminbi appreciation by monetary contraction.

\section{Taxing trade}

The other 'unhealthy' approach to a unilateral appreciation is via trade distortions. We can dismiss a rise in import tariffs since China's WTO accession conditions offer very little room between applied and bound tariff rates. Export restraints are possible, however - of the type followed by Japan in the late 1980s when it was under similar pressure from the United States. These are not directly protectionist and hence would not attract mercantilist objections from abroad. In principle at least, like import tariffs, they might be expected to divert domestic demand from foreign to home products and thereby appreciate the real exchange rate, allowing the central bank to also appreciate the nominal exchange rate. The downside is that they would also be a tax on the most rapidly expanding sectors in the economy so they would sacrifice growth in urban employment and income.

The corresponding Tyers and Zhang (2010) simulation is of the short-run impacts of an export tax of 15 per cent graduated over 2007-09 and levied only on industrial exports. As previously, they consider scenarios with optimistic and pessimistic households. Surprisingly, in both cases, China experiences robust real depreciations against North America. This is because China's current account surplus rises even in the optimistic case, in which the saving rate falls temporarily. This contradicts the expected story because that emphasises substitution in final demand. The true story is about intermediate

18 Ito (2001:Ch. 11, pp. 329-33) shows that, in the post-Plaza Accord period, the yen appreciated substantially against the US dollar and Japan's current account surplus rose at the same time, even while real investment also rose. 
demand. China's export-manufacturing sector relies to an extraordinary extent on imported components - mostly from Asian trading partners. ${ }^{19}$ When the export tax contracts this sector, imports are similarly contracted. Total exports, in fact, contract by a smaller proportion because there is offsetting expansion in agricultural and service exports that are not intensive in imported inputs. The net effect is an expansion in China's trade surplus.

In North America, the current account deficit rises and, as before, there are only small changes in real GDP and real per capita income. Importantly, however, China's export restraints do raise North American industrial employmentagain, at the expense of services employment - even though North America experiences a real appreciation against China that would otherwise advantage the services sector. In either case, at least in the short run, export restraints would not make it easier for the PBOC to appreciate the renminbi; in fact, quite the opposite.

\section{Conclusions}

Relative to the United States, Chinese productivity has grown faster in tradable than in non-tradable sectors, real wages have also grown faster and there has been relative service-price inflation. The flat trajectory of its real exchange rate between 1990 and 2004 is therefore a contradiction of the BSH, the resolution of which requires generalisation to incorporate failures of the law of one price for tradable goods, open financial capital markets and a more sophisticated representation of the labour market. This opens the way for depreciating forces that have offset the $\mathrm{BSH}$, including net financial outflows on the balance of payments associated with China's excess saving along with trade and other microeconomic reforms. Decomposition of the flat trajectory of the real exchange rate during 1997-2004 reveals that the BSH was offset most strongly by the excess saving and the associated expansion of net outflows on its capital account, along with a significant additional contribution from WTO accession trade reforms. China's real exchange rate began appreciating in the mid 2000s when the national saving rate stabilised and trade reforms were exhausted. An examination of the trends in relative product prices and real wages in this period suggests that the real appreciation is not due to the resumption in the dominance of the BSH. Instead it appears to be due to tightening rural labour markets associated with improvements in the agricultural terms of trade, combined with slowing overall labour force growth.

19 An important empirical literature is developing around China's role as an assembler of components made in other Asian countries. Part of the reason for China's bilateral trade surplus with the United States is that this intra-Asian trade is reducing the bilateral surpluses of other Asian economies with the United States while it exacerbates that of China. See, for example, Athukorala $(2005,2007)$. 
While much attention is paid in the literature to the past decade's 'undervaluation' of the renminbi, it is in our view incorrect to blame this on China's monetary policy - narrowly defined to include the exchange rate target and the accumulation of foreign exchange reserves. The key constraints were capital controls, motivated by concern about financial (and exchange rate) stability in the face of the relative immaturity of its commercial banking sector, and structurally determined high savings. These constraints will eventually be relaxed but, while they remain, reserves will accumulate and exchange rate adjustment will not address the current account imbalance. The only 'healthy' way to appreciate the renminbi will be to follow the path of the underlying real exchange rate. We show that defiance of this principle in the form of a unilateral appreciation by monetary contraction would be very costly to China - and it would most likely hurt the rest of the world by tightening capital markets and changing the terms of trade adversely. Moreover, if Chinese households were to react pessimistically to the shock, the current account surplus could be enlarged, backfiring on those who clamour for an appreciation to address global imbalances. The other conceptually feasible, but no more healthy, approach to a unilateral appreciation is via the imposition by China of a tax on manufactured exports. As it turns out, because China's export-manufacturing sector relies so heavily on imported components, such a tax would in fact exacerbate the trade surplus by cutting imports in proportion with manufactured exports while expanding other less import-dependent exports. This would increase China's current account surplus while sacrificing considerable growth. It would hurt the North American economy overall.

In the near term, with an apparently labour market-driven appreciating trend in the underlying real exchange rate, it is reasonable for the central bank to allow a unilateral nominal appreciation of the renminbi to ease domestic inflation pressure. To the extent that this appreciating trend is not fast enough for political equilibria in China's trading partners, international pressure would best be focused on the remaining financial reforms, including smooth transitions to policies that better regulate large SOEs and address the need for uniform systems of retirement and health insurance. In the long term, whether there is a sustained upward trend in China's real exchange rate will depend on the relative strengths of appreciating forces, including tradable productivity growth, reduced savings and labour force decline, and depreciating forces, including productivity growth in its services sector. 


\section{References}

Aizenman, J. and Lee, J. 2006, Financial versus monetary mercantilism: long run view of large international reserves hoarding, IMF Working Paper WP/06/280, International Monetary Fund, Washington, DC.

Anderson, K. (ed.) 2009, Distortions to Agricultural Incentives: A global perspective, 1955-2007, Palgrave Macmillan and The World Bank, London and Washington, DC.

Anderson, K. and Hayami, Y. 1986, Political Economy of Agricultural Protection: The experience of East Asia, Chinese Academy of Social Sciences, Beijing [1996 publication in Chinese based on the original, Allen \& Unwin, Sydney].

Athukorala, P.-C. 2005, 'Components trade and implications for Asian structural adjustment', in R. Garnaut and L. Song (eds), The China Boom and Its Discontents, Asia Pacific Press, Canberra.

Athukorala, P.-C. 2007, The rise of China and its consequences for East Asia: is the fear of export competition warranted?, Conference on Reforms for Korea's Sustained Growth, East West Centre and Korea Development Institute, Honolulu, 12-13 July.

Balassa, B. 1964, 'The purchasing power parity doctrine: a reappraisal', Journal of Political Economy, vol. 72, no. 6, pp. 584-96.

Bayoumi, T., Tong, H. and Wei, S. J. 2009, The Chinese corporate savings puzzle: a firm-level cross-country perspective, Columbia Business School Working Paper, December, Columbia University, New York.

Bergin, P. R., Glick, R. and Taylor, A. M. 2006, 'Productivity, tradability and the long run price puzzle', Journal of Monetary Economics, vol. 53, no. 8, pp. 41-66.

Bernanke, B. 2006, Speech to the Chinese Academy of Social Sciences, Beijing, 15 Friday December, <www.federalreserve.gov/BoardDocs/ Speeches/2006/20061215>

Cai, F. and Wang, D. 2006, 'Employment growth, labour scarcity and the nature of China's trade expansion', in R. Garnaut and L. Song (eds), The Turning Point in China's Economic Development, Asia Pacific Press, Canberra.

Callan, E. 2007, 'Clinton and Obama back China crackdown', The Financial Times, 5 July. 
Chamon, M. and Prasad, E. 2008, Why are saving rates of urban households in China rising?, Global Economy and Development Working Paper 31, December, Brookings Institution, Washington, DC.

Chang, J. and Tyers, R. 2008, 'Trade reform, macroeconomic policy and sectoral labour movement in China', in C. Chen and R. Duncan (eds), The Impact of WTO Accession and Regional Trade Arrangements on China's Agricultural Sector and Food Security, Asia Pacific Press, Canberra, pp. 268-304.

Cheung, Y.-W., Chinn, M. and Fuji, E. 2007a, China's current account and exchange rate, Center for Economic Studies CESifo Working Paper Series no. 2587, Ludwig Maximilian University of Munich.

Cheung, Y.-W., Chinn, M. and Fuji, E. 2007b, 'The overvaluation of renminbi undervaluation', Journal of International Money and Finance, vol. 26, pp. 762-85.

Cline, W. 2005, The case for a new Plaza agreement, Policy Briefs 05-4, Institute for International Economics, Washington, DC.

Coudert, V. and Couharde, C. 2005, Real equilibrium exchange rate in China, CEPII Working Paper No. 2005-01, CEPII, Paris.

Crucini, M. J., Telmer, C. I. and Zachariadis, M. 2005, 'Understanding European real exchange rates', American Economic Review, vol. 95, no. 3, pp. 724-38.

Dixon, P. B. and Rimmer, M. T. 2002, Dynamic General Equilibrium Modelling for Forecasting and Policy: A practical guide and documentation of Monash, North Holland, Amsterdam.

Dixon, P. B., Parmenter, B. R., Suttonand, J. and Vincent, D. P. 1982, ORANI: A multi-sectoral model of the Australian economy, North Holland, Amsterdam.

Dooley, M. P., Folkerts-Landau, D. and Garber, P. 2003, An essay on the revived Bretton Woods system, NBER Working Paper 9971, National Bureau of Economic Research, Cambridge, Mass.

Drine, I. and Rault, C. 2005, 'Can the Balassa-Samuelson theory explain long run real exchange rate movements in OECD countries?', Applied Financial Economics, vol. 15, no. 8, pp. 519-30.

Duncan, R., Rees, L. and Tyers, R. 2008, 'Revisiting the economic costs of food self-sufficiency in China', in C. Chen and R. Duncan (eds), The Impact of WTO Accession and Regional Trade Arrangements on China's Agricultural Sector and Food Security, Asia Pacific Press, Canberra, pp. 203-28. 
China; The Next Twenty Years of Reform and Development

Feenstra, R. C. and Hong, C. 2007, China's exports and employment, NBER Working Paper 13552, October, National Bureau of Economic Research, Cambridge, Mass.

Fogel, R. 2006, Why is China likely to achieve its growth objectives?, NBER Working Paper W12122, National Bureau of Economic Research, Cambridge, Mass.

Frankel, J. 2004, On the renminbi: the choice between adjustment under a fixed exchange rate and adjustment under a flexible rate, NBER Working Paper 11274, National Bureau of Economic Research, Cambridge, Mass.

Gardner, B. 2010, 'China's labor situation is changing, not for the worse', Roubini Global Economics - Asia EconoMonitor, 1 June.

Garnaut, R. and Huang, Y. 2006, 'Mature Chinese growth leads the global Platinum Age', in R. Garnaut and L. Song (eds), China: Linking markets for growth, Asia Pacific Press, Canberra.

Golley, J. and Tyers, R. 2006, 'China's growth to 2030: demographic change and the labour supply constraint', in R. Garnaut and L. Song (eds), The Turning Point in China's Economic Development, Asia Pacific Press, Canberra.

Goldstein, M. 2004, Adjusting China's foreign exchange rate, International Monetary Fund seminar on China's Foreign Exchange Rate System, Dalian, China.

Gordon, R. 2003, 'Exploding productivity growth: context, causes and implications', Brookings Papers on Economic Activity, vol. 2, pp. 207-97.

Gordon, R. 2006, The US productivity growth 'explosion': dimensions, causes, consequences and aftermath, 48th Annual Meeting of the NABE, NBER Session, Boston, 11 September.

Hertel, T. W. (ed.) 1997, Global Trade Analysis Using the GTAP Model, Cambridge University Press, New York.

Huang, J., Rozelle, S., Martin, W. and Liu, Y. 2009, 'China', in K. Anderson (ed.), Distortions to Agricultural Incentives: A global perspective, 1955-2007, Palgrave Macmillan and The World Bank, London and Washington, DC.

International Monetary Fund (IMF) 2009a, International Financial Statistics, International Monetary Fund, Washington, DC.

International Monetary Fund (IMF) 2009b, World Economic Outlook Database, April, International Monetary Fund, Washington, DC. 
International Monetary Fund (IMF) various issues, International Financial Statistics, International Monetary Fund, Washington, DC.

Ito, T. 2001, The Japanese Economy, MIT Press, Cambridge, Mass.

Lardy, N. 2006, 'China's interaction with the global economy', in R. Garnaut and L. Song (eds), The Turning Point in China's Economic Development, Asia Pacific Press, Canberra.

Lu, F. 2006, China's productivity growth: an international comparison, China Centre for Economic Research Working Paper C200604, Peking University, Beijing.

Lu, F., Song, G., Tang, J., Zhao, H. and Liu, L. 2008, 'Profitability of Chinese industrial firms (1978-2006)', China Economic Journal, vol. 1, no. 1, pp. 1-31.

Ma, G. and McCauley, R. N. 2007, 'How effective are China's capital controls?', in R. Garnaut and L. Song (eds), China: Linking markets for growth, Asia Pacific Press, Canberra.

McKibbin, W. J. and Sachs, J. 1991, Global Linkages: Macroeconomic independence and cooperation in the world economy, Brookings Institution, Washington, DC.

McKinnon, R. I. 2004, 'The East Asian dollar standard', China Economic Review, vol. 15, pp. 325-30.

McKinnon, R. I. 2006, 'China's exchange rate appreciation in the light of the earlier Japanese experience', Pacific Economic Review, vol. 11, no. 3, pp. 287-98.

Meng, X. and Bai, N. 2007, 'How much have the wages of unskilled workers in China increased? Data from seven factories in Guangdong', in R. Gaunaut and L. Song (eds), China:Linking markets for growth, Asia Pacific Press, Canberra.

Ministry of Commerce of the People's Republic of China 2009, China Foreign Trade and Economic Cooperation Gazette 2005-2009, Ministry of Commerce of the People's Republic of China, Beijing.

National Bureau of Statistics (NBS) 2009, China Statistical Yearbook 2009, China Statistics Press, Beijing.

People's Bank of China (PBOC) 2009, Balance Sheet of Monetary Authority, People's Bank of China, Beijing.

People's Bank of China (PBOC) various issues, Balance Sheet of Monetary Authority, People's Bank of China, Beijing. 
China; The Next Twenty Years of Reform and Development

Prasad, E., Rumbaugh, T. and Wang, Q. 2005, Putting the cart before the horse: capital account liberalization and the exchange rate in China, Policy Discussion Paper 05/01, International Monetary Fund, Washington, DC.

Rees, L. and Tyers, R. 2004, 'Trade reform in the short run: China's WTO accession', Journal of Asian Economics, vol. 15, no. 1, pp. 1-31.

RGE Monitor (2007), 'Excessive Liquidity and Credit Growth in Emerging Markets', 11 May, info@rgemonitor.com.

Roland-Holst, D., Brooks, D. and Zhai, F. 2005, Asia's long term growth and integration: reaching beyond trade policy barriers, ADB Policy Brief No. 38, Asian Development Bank, Manila.

Samuelson, P. 1964, 'Theoretical notes on trade problems', Review of Economics and Statistics, vol. 46, no. 2, pp. 145-54.

Tung, C. Y. and Baker, S. 2004, 'RMB revaluation will serve China's self-interest', China Economic Review, vol. 15, pp. 331-5.

Tyers, R. and Golley, J. 2008, 'China's real exchange rate puzzle', Journal of Economic Integration, vol. 23, no. 3, pp. 547-74.

Tyers, R. and Golley, J. (forthcoming), 'China's growth to 2030: the roles of demographic change and investment reform', Review of Development Economics, [earlier version in Chinese published in China Labour Economics, vol. 4, no. 1 (2007), pp. 6-30].

Tyers, R. and Lu, F. 2009, Competition policy, corporate saving and China's current account surplus, Working Papers in Economics and Econometrics No. 496, July, College of Business and Economics, The Australian National University, Canberra.

Tyers, R. and Zhang, Y. 2010, Appreciating the renminbi, Working Paper, Business School, University of Western Australia, Perth.

Tyers, R., Golley, J., Bu, Y. and Bain, I. 2008, 'China's economic growth and its real exchange rate', China Economic Journal, vol. 1, no. 2, pp. 123-45.

Wang, T. 2004, 'Exchange rate dynamics', in E. Prasad (ed.), China's growth and integration into the world economy: prospects and challenges, IMF Occasional Paper 232, International Monetary Fund, Washington, DC.

Wen, J. 2008, Report on the work of the government, Speech, Beijing.

Wen, J. 2010, Report on the work of the government, Speech, Beijing. 
Woo, W. T. 2006, 'China's macroeconomic imbalances: the liquidity tango mechanism', in J. J. Teunissen and A. Akkerman (eds), Global Imbalances and the US Debt Problem: Should developing countries support the US dollar?Volume 1, Forum on Debt and Development, The Hague.

World Trade Organisation (WTO) 2008, Trade Policy Review: China, WT/ TPR/G/199, World Trade Organisation, Washington, DC.

Xiao, G. 2006, What is special about China's exchange rate and external imbalance: a structural and institutional perspective, Asian Economic Panel 2007, Brookings-Tsinghua Center and Brookings Institution, Beijing and Washington, DC.

US Bureau of Labor Statistics various issues, Producer Price Index Detailed Reports, US Bureau of Labor Statistics, Washington, DC.

\section{Acknowledgments}

Funding for the research described in this chapter came from the Australian Research Council Discovery Grant No. DP0557889. Thanks are due to Iain Bain and Pingkun Hsu for their assistance with the analysis presented in an earlier draft and to Jane Golley, Yongxiang Bu, Huang Yiping, Ross Garnaut, Yanrui Wu and Wing Thye Woo for useful discussions on the topic. 